\title{
SIKAP ISI RUMAH TERHADAP HUTANG DAN KEBERHUTANGAN: KAJIAN KES DI LEMBAH KLANG, MALAYSIA
}

\section{Nurshahirah Azman}

Calon Ph.D, Jabatan Ekonomi, Fakulti Ekonomi dan Pentadbiran, Universiti

Malaya.

\section{Roza Hazli Zakaria, PhD}

Pensyarah Kanan, Jabatan Ekonomi, Fakulti Ekonomi dan Pentadbiran, Universiti Malaya. roza@um.edu.my

\section{Sabitha Marican, PhD}

Profesor Madya, Jabatan Pengajian Pentadbiran Politik, Fakulti Ekonomi dan Pentadbiran, Universiti Malaya. sabitha@um.edu.my

The number of household indebtedness in Malaysia is much higher than that of other countries with comparable per capita income. A study was conducted to analyze households' attitudes towards debt and its relation with household indebtedness. Using the Klang Valley population as the sample, and a binary logit regression analysis, the study found that attitudes play a role in determining a household indebtedness. However, data from the factors attitude formation suggest that variables such as religion, ethnicity, and social norms were influential in determining households' attitudes towards debt. The study suggests those positive households' attitudes towards debt and indebtedness can be enhanced through education intervention. A proper knowledge about debt may minimize household's problem related to excessive indebtedness, which are crucial for the maintenance of their well-being.

Kata kunci: Hutang, keberhutangan, sikap isi rumah. 


\section{PENGENALAN}

Statistik menunjukkan peningkatan isi rumah di Malaysia adalah pada kadar yang membimbangkan. Laporan Bank Negara Malaysia (BNM) 2010 merekodkan nisbah hutang isi rumah terhadap pendapatan negara telah meningkat dengan mendadak kepada 76.6 peratus pada tahun 2009 di mana ianya merupakan tertinggi di Asia (tidak termasuk Jepun). Nisbah hutang isi rumah terhadap pendapatan boleh guna individu mencatatkan $140.4 \%$ pada tahun 2009, iaitu lebih tinggi daripada Singapura (105.3\%) dan Amerika Syarikat (123.3\%) (S.M. Mohamed, 2011). Nisbah hutang isi rumah yang tinggi ini merupakan sesuatu yang membimbangkan kerana nisbah hutang isi rumah yang tinggi terhadap pendapatan boleh guna adalah penentu kepada financial distress (Kee, 2010).

Kemungkinan keberhutangan isi rumah yang tinggi untuk membawa kepada pelbagai kesan buruk khususnya dari aspek kestabilan kewangan daripada peringkat mikro sehinggalah kepada peringkat makro, secara semulajadinya telah memotivasikan kajian-kajian ilmiah tentang permasalahan ini. Antara kajian yang dijalankan adalah mengenai faktorfaktor yang menyebabkan keberhutangan yang tinggi di dalam kalangan isi rumah dan pengaruhnya di dalam menggugat kestabilan kewangan keluarga dan negara.

Pada peringkat mikro atau isi rumah, kajian-kajian yang dijalankan untuk menerangkan mengapa isi rumah berhutang menyimpulkan sebab utama isi rumah berhutang tidak terhad hanya kepada faktor memenuhi keperluan hidup, pendapatan yang rendah dan bilangan anak yang ramai (Wang et al., 2011; Kamleitner dan Kirchler, 2007). Sebaliknya, fenomena keberhutangan isi rumah turut disebabkan oleh faktor yang menunjukkan pengambilan hutang bagi memenuhi kehendak seperti sikap materialistik dan mempunyai aspirasi hidup yang tinggi. Selain itu, sikap atau atitud isi rumah terhadap hutang juga merupakan faktor yang dikesan sebagai turut mendorong gejala keberhutangan. Bagaimanapun, pengaruh sikap terhadap hutang adalah unik kerana bersikap terbuka terhadap hutang tidak semestinya akan membawa kepada keberhutangan. Ini berasaskan kajiankajian psikologi yang menunjukkan sikap dan tingkah laku tidak semestinya konsisten (Azjen, 1996).

Kenyataan ini menimbulkan persoalan "setakat mana peranan sikap mendasari keberhutangan isi rumah di Malaysia?" Statistik keberhutangan isi rumah mengisyaratkan kadar hutang isi rumah di Malaysia secara puratanya, jauh melangkaui nisbah bayar balik hutang bulanan kepada pendapatan bulanan isi rumah yang diiktiraf sebagai selamat oleh pihak 
perbankan (The Star, April 2011). Adakah keberhutangan yang melampau ini disebabkan oleh sikap isi rumah yang terlalu pro hutang? Maka kajian ini dijalankan dengan tujuan untuk menganalisa secara lebih terperinci sikap isi rumah di Malaysia terhadap hutang dan untuk mengenalpasti hubungan antara sikap terhadap hutang dengan keadaan keberhutangan isi rumah.

Kajian untuk memahami gelagat isi rumah, khususnya yang melibatkan faktor sikap isi rumah diperlukan untuk mencadangkan kaedah yang sesuai bagi membantu mengurangkan kadar keberhutangan isi rumah. Jika bukti empirik mencadangkan sikap pro hutang masyarakat Malaysia menyumbang kepada keberhutangan isi rumah, pendidikan tentang kesan buruk amalan berhutang tanpa kawalan mungkin boleh membantu mengawal gelagat keberhutangan isi rumah. Bantuan kewangan atau subsidi sematamata tidak akan dapat mengurangkan masalah keberhutangan kerana ia tidak akan mengubah gelagat keberhutangan isi rumah.

\section{PENENTU KEBERHUTANGAN ISI RUMAH}

Keberhutangan isi rumah bukan satu isu yang baru, khususnya di negara maju. Selari dengan itu, kajian lepas yang berkaitan dengan keberhutangan isi rumah boleh dikatakan agak banyak. Memandangkan fokus kajian adalah kepada sikap isi rumah terhadap hutang, sorotan karya juga ditumpukan kepada kajian terdahulu yang mengkaji faktor sikap.

\section{Konsep sikap dan komponennya}

Perkataan 'attitude' atau sikap berasal daripada terma bahasa Latin iaitu aptus yang bermaksud sesuai atau kesesuaian (Ramayah et al., 2002). Manakala Plotnik dan Kouyoumdjian (2008) pula mendefinisikan sikap sebagai kepercayaan atau pendapat yang melibatkan penilaian tentang sesuatu objek, individu atau sesuatu kejadian dan ianya mempengaruhi perlakuan individu tersebut dalam cara yang khusus terhadap objek, individu atau kejadian yang dinilai. Oleh itu, sikap boleh didefinisikan sebagai penilaian seseorang individu terhadap sesuatu (individu lain, objek atau isu) yang merangkumi komponen perasaan (suka, tidak suka atau neutral) dan ianya diterjemahkan melalui perbuatan/tindakan.

Menurut teori psikologi, terdapat tiga asas sikap iaitu emosi, rasional dan tingkah laku individu pada masa lepas yang digunakan sebagai pendekatan dalam memahami pembentukan sikap (Olson dan Kendrick, 2008). Komponen-komponen tersebut dikenali sebagai pendekatan "tripartite" atau model komponen sikap ABC (Affect, Behavior, Cognition). 
Ia melibatkan perhubungan di antara pengetahuan, perasaan dan perbuatan yang digunakan oleh individu dalam membuat penilaian tentang sesuatu, dalam kes ini adalah sikap terhadap hutang.

Komponen kognitif adalah kepercayaan, pengetahuan dan sifat-sifat yang berkaitan dengan sesuatu objek. Seseorang individu mempunyai kepelbagaian sikap yang menunjukkan suka dan tidak suka terhadap sesuatu dan ianya kerapkali terjadi secara automatik iaitu terjadi tanpa sedar (Plotnik dan Kouyoumdjian, 2008). Cosma dan Pattarin (2010) menyifatkan komponen kognitif yang berkaitan dengan hutang adalah merujuk kepada keseluruhan set maklumat, kepercayaan, pendapat di mana individu menjadi matang dalam fasa hidupnya berpandukan pengalaman mereka sendiri dan interaksi dengan keadaan sekeliling.

Komponen afektif (affective) pula merujuk kepada perasaan atau emosi yang berkaitan terhadap sesuatu objek/isu (Maio dan Haddock, 2010). Manakala Plotnik dan Kouyoumdjian (2008) pula mendefinisikan komponen afektif sebagai perasaan emosi yang boleh menjadi lemah atau kuat dan kecenderungan darjah positif atau negatif. Sebagai contoh, perasaan yang timbul akibat daripada penggunaan kredit atau perasaaan sekiranya berada di dalam situasi berhutang (Cosma dan Pattarin, 2010).

Sementara itu, komponen tingkah laku (behavior) merujuk kepada tindakan atau perbuatan yang ingin dilakukan akibat daripada membuat rujukan terhadap tingkah laku lepas atau pengalaman mengenai sesuatu isu (Maio \& Haddock, 2010). Komponen tingkah laku boleh dijustifikasi berpandukan teori persepsi, iaitu situasi di mana individu memerhatikan bagaimana tingkah laku mereka dan membuat keputusan mengenai sikap mereka dengan mengingati bagaimana mereka bertindak atau berkelakuan terhadap isu tersebut pada masa lepas.

\section{Hubungan sikap dengan keadaan keberhutangan isi rumah}

Selari dengan teori psikologi, kajian yang melibatkan faktor sikap terbahagi kepada dua; iaitu yang mendefinisikan sikap secara umum dan yang mengasingkan sikap kepada tiga komponen yang berbeza. Antara pengkaji yang melihat pembolehubah sikap dengan mengelaskannya secara spesifik mengikut Model Sikap ABC (Affect, Behavior, Cognition) dan hubungannya terhadap keberhutangan adalah Cosma dan Pattarin, (2010) dan Wang et al., (2011). Kajian-kajian mereka menyokong kewujudan pengaruh sikap ke atas keberhutangan isi rumah, menerusi komponen yang berbeza. Misalnya, Cosma dan Pattarin (2010) mendapati ketiga-tiga komponen sikap mempengaruhi tahap penggunaan kredit masyarakat Itali. Manakala kajian 
oleh Wang et al. (2011) pula mendapati sikap isi rumah mempengaruhi hutang; tetapi hanya dari dimensi afektif dan tingkah laku.

Selain itu, kajian Cosma dan Pattarin (2010) dan Wang et al. (2011) juga mendapati sikap memainkan peranan yang penting di dalam menentukan jenis kredit yang digunakan oleh isi rumah. Cosma dan Pattarin (2010) mendapati isi rumah yang pro kredit semakin cenderung untuk membiayai penggunaan isi rumah dengan kad kredit atau pinjaman tempat jualan (point of sale lending) berbanding dengan pinjaman peribadi dan pinjaman dari gaji (salary loans). Malah, komponen kognitif dikatakan memainkan peranan yang penting dalam menentukan rangka pembuatan keputusan yang diambil oleh isi rumah dalam menentukan jenis kredit yang mereka ingini.

Sementara kajian lain yang mengukur sikap secara umum, antaranya adalah Davies dan Lea (1995) dan Zafar et al. (2010). Keduanya melaporkan keputusan yang berbeza. Davies dan Lea (1995) mendapati sikap terhadap hutang mempengaruhi keberhutangan dalam kalangan mahasiswa ijazah pertama yang dikaji. Sebaliknya, Zafar et al. (2010) melaporkan sikap atau kecenderungan terhadap hutang tidak menerangkan jumlah hutang kad kredit di Malaysia. Perbezaan dapatan kajian ini mungkin disebabkan golongan yang dikaji. Davies dan Lea (1995) hanya mengambilkira golongan mahasiswa universiti yang mempunyai jangkaan optimistik terhadap pendapatan masa depan, berbanding Zafar et al. (2010) yang mengkaji golongan awam.

Bagaimanapun, sumbangan unik kajian Davies dan Lea (1995) adalah dalam menunjukkan bahawa sikap terhadap hutang adalah sesuatu yang dinamik. Tahap keberhutangan dan sikap terhadap hutang didapati berbeza bagi ketiga-tiga tahun pengajian. Terdapat peningkatan di dalam jumlah hutang dan perubahan sikap terhadap hutang daripada anti kepada pro, apabila pelajar berada dalam tahun ketiga pengajian, berbanding dengan ketika berada pada tahun 1. Corak ini disahkan oleh analisis regresi yang mendapati tahap keberhutangan berubah dengan drastik di antara tahun pengajian 1 dan 2 manakala perubahan dari segi sikap berlaku di antara tahun pengajian 2 dan 3. Oleh itu, Davies dan Lea (1995) menyimpulkan pelajar pada awal pengajian mereka tidak terdedah terhadap hutang. Namun, mereka mendapati diri mereka berada di dalam situasi di mana berhutang dilihat sebagai suatu kemudahan dan mereka mempunyai pandangan positif terhadap jangkaan pendapatan pada masa depan. Ini menyebabkan sikap mereka terhadap hutang berubah pada tahun ke 2 dan ke 3. 


\section{Faktor-faktor Ekonomi dan Sosio-Demografi dan Keberhutangan isi rumah}

Selain daripada faktor sikap, kajian lepas turut mengenalpasti faktor lain yang turut mempengaruhi keberhutangan isi rumah. Dapatan kajian berhubung faktor lain diringkaskan dalam Jadual 1.

\section{Jadual 1: Ringkasan Sorotan Karya Faktor Yang Mempengaruhi Keberhutangan Isi Rumah}

\begin{tabular}{|c|c|c|c|}
\hline $\begin{array}{l}\text { Pengkaji } \\
\text { (Tahun) }\end{array}$ & Objektif Kajian & $\begin{array}{c}\text { Metodologi utama dan } \\
\text { Perincian Data }\end{array}$ & Dapatan Kajian \\
\hline $\begin{array}{l}\text { Legge dan } \\
\text { Heynes } \\
(2009)\end{array}$ & $\begin{array}{l}\text { Menguji keberhutangan } \\
\text { keluarga New Zealand } \\
\text { dan mengenalpasti } \\
\text { keadaaan dan tingkah } \\
\text { laku yang membezakan } \\
\text { keluarga yang } \\
\text { menggunakan hutang } \\
\text { dengan baik atau } \\
\text { sebaliknya }\end{array}$ & $\begin{array}{l}\text { Analisis diskriptif } \\
\text { daripada data survei }\end{array}$ & $\begin{array}{l}\text { Faktor } \\
\text { keberhutangan isi } \\
\text { rumah } \\
\text { dipengaruhi oleh } \\
\text { pendapatan isi } \\
\text { rumah yang } \\
\text { rendah, umur dan } \\
\text { status } \\
\text { perkahwinan. } \\
\text { Cadangan polisi } \\
\text { adalah } \\
\text { meningkatkan } \\
\text { pendapatan }\end{array}$ \\
\hline $\begin{array}{l}\text { Ramayah } \\
\text { et al. (2002) }\end{array}$ & $\begin{array}{l}\text { Mengkaji perhubungan } \\
\text { di antara sikap } \\
\text { pemegang kad kredit dan } \\
\text { penggunaannya bagi } \\
\text { membezakan pengguna } \\
\text { kad kredit aktif dan tidak } \\
\text { aktif. } \\
\text { Kajian juga turut } \\
\text { mengenal pasti } \\
\text { perhubungan di antara } \\
\text { faktor demografi dan } \\
\text { sosio-ekonomi terhadap } \\
\text { penggunaan kad kredit. }\end{array}$ & $\begin{array}{l}\text { Data dikumpul } \\
\text { menggunakan borang } \\
\text { soal-selidik yang } \\
\text { diedarkan di Malaysia } \\
\text { dengan menggunakan } \\
\text { metod persampelan } \\
\text { bukan kebarangkalian. } \\
\text { Analisis kajian } \\
\text { menggunakan analisis } \\
\text { diskriminan bagi } \\
\text { pembolehubah sikap. } \\
\text { Manakala, analisis chi- } \\
\text { square digunakan bagi } \\
\text { menguji faktor-faktor } \\
\text { demografi terhadap } \\
\text { tahap penggunaan kad } \\
\text { kredit. }\end{array}$ & $\begin{array}{l}\text { Kecenderungan } \\
\text { isi rumah untuk } \\
\text { berhutang } \\
\text { ditentukan oleh } \\
\text { pendapatan dan } \\
\text { jenis pekerjaan. }\end{array}$ \\
\hline
\end{tabular}




\section{Sambungan Jadual 1}

\begin{tabular}{|c|c|c|c|}
\hline $\begin{array}{l}\text { Livingstone } \\
\text { dan Lunt } \\
(1992)\end{array}$ & $\begin{array}{l}\text { Membezakan ciri-ciri isi } \\
\text { rumah yang berhutang } \\
\text { dan tidak berhutang. } \\
\text { Memahami faktor-faktor } \\
\text { yang menyebabkan } \\
\text { seseorang individu } \\
\text { meminjam lebih } \\
\text { daripada orang lain. }\end{array}$ & $\begin{array}{l}\text { Menggunakan kaedah } \\
\text { soal-selidik di kalangan } \\
\text { isi rumah di United } \\
\text { Kingdom dan } \\
\text { menggunakan kaedah } \\
\text { persampelan } \\
\text { snowballing. } \\
\text { Analisis data } \\
\text { menggunakan analisis } \\
\text { fungsi diskriminasi bagi } \\
\text { membezakan kelompok } \\
\text { berhutang dan tidak } \\
\text { berhutang (faktor } \\
\text { ekonomi, demografi dan } \\
\text { psikologi). }\end{array}$ & $\begin{array}{l}\text { Faktor yang } \\
\text { membezakan isi } \\
\text { rumah yang } \\
\text { berhutang dan } \\
\text { tidak berhutang } \\
\text { adalah } \\
\text { pendapatan, } \\
\text { tabungan, sikap } \\
\text { terhadap kredit } \\
\text { dan usia. }\end{array}$ \\
\hline $\begin{array}{l}\text { Ottaviani } \\
\text { dan Vandone } \\
(2010)\end{array}$ & $\begin{array}{l}\text { Meramal peranan faktor } \\
\text { emosi dalam } \\
\text { menentukan penglibatan } \\
\text { dalam pasaran hutang } \\
\text { dengan memasukkan } \\
\text { pembolehubah peramal } \\
\text { ekonomi dan sosio } \\
\text { demografi. }\end{array}$ & $\begin{array}{l}\text { Sampel kajian diambil } \\
\text { daripada bangsa } \\
\text { Kaukasian yang dipilih } \\
\text { secara rawak di kalangan } \\
\text { pekerja sepenuh masa di } \\
\text { syarikat pengurusan aset } \\
\text { antarabangsa. } \\
\text { Data dianalisis } \\
\text { menggunakan model } \\
\text { probit bagi mengkaji } \\
\text { kebarangkalian } \\
\text { responden kajian } \\
\text { mempunyai hutang. }\end{array}$ & $\begin{array}{l}\text { Faktor yang } \\
\text { menentukan } \\
\text { kebarangkalian } \\
\text { responden kajian } \\
\text { mempunyai } \\
\text { hutang } \\
\text { adalahpendapatan } \\
\text { dan jenis } \\
\text { pekerjaan. }\end{array}$ \\
\hline
\end{tabular}

\section{Pembentukan Sikap Terhadap Hutang Isi Rumah}

Selain daripada itu, kajian turut melihat kepada apakah faktor yang mendasari pembentukan sikap terhadap hutang. Bagaimanapun, kajian yang mengkaji isu ini adalah agak terhad. Antara pengkaji utama adalah Davies dan Lea (1995), Wickramasinghe dan Gurugamage (2012); Lee et al., 2007/2011; Zuroni dan Lin (2012) serta Abdul Muhmin dan Umar (2004). Faktor yang didapati menyumbang kepada kecenderungan seseorang individu untuk bersikap pro hutang adalah jumlah hutang yang tinggi, iaitu keadaan di mana jumlah hutang akan memberikan kesan positif dan signifikan terhadap sikap individu (Davies dan Lea, 1995; Wang et al., 2011). 
Selain itu, tahap pendidikan juga mempengaruhi sikap terhadap hutang. Individu yang memiliki tahap pendidikan yang tinggi cenderung untuk memiliki kepercayaan kredit yang tinggi dan yakin terhadap status kewangan mereka pada masa depan (Kim dan DeVaney, 2001). Malah, faktor agama turut merupakan faktor utama yang mempengaruhi pembentukan sikap terhadap hutang, sebagaimana dapatan oleh Davies dan Lea (1995)yang melaporkan responden yang bukan beragama Kristian cenderung untuk bersikap pro hutang. Kajian oleh Abdul Muhmin dan Umar (2004) yang dilakukan di kalangan responden di Arab Saudi yang beragama Islam pula mendapati mereka mempunyai sikap negatif terhadap kredit dan juga kad kredit. Malah, dapatan kajian oleh Universities UK (2003) juga menyokong premis bahawa mereka yang berbangsa Pakistan dan beragama Islam kurang cenderung terhadap hutang.

Secara keseluruhannya, sorotan kajian lepas menunjukkan keputusan kajian-kajian lepas setakat ini adalah tidak konsisten. Ini seterusnya menunjukkan walaupun masalah hutang isi rumah adalah universal, faktor-faktor yang mendorong individu dan isi rumah untuk berhutang adalah unik untuk setiap kumpulan populasi negara. Oleh itu, setiap masyarakat memerlukan kajian tersendiri untuk menentukan keadaan keberhutangan isi rumah, bagi mengarahkan kepada cadangan polisi yang bersesuaian.

Namun, ketersediaan kajian empirikal setakat ini lebih tertumpu kepada negara-negara maju seperti United Kingdom, Amerika Syarikat, New Zealand dan Itali yang sememangnya mempunyai perbezaan dari segi budaya dan akses terhadap pinjaman. Hanya sedikit kajian empirikal tentang keberhutangan yang dilakukan di negara-negara sedang membangun (Wang et al., 2011). Justeru, adalah penting kajian empirikal sebegini diperluaskan kepada negara-negara sedang membangun khususnya Malaysia, yang mencatatkan kadar keberhutangan isi rumah yang relatif tinggi. Tindakan ini penting untuk memberikan garis panduan terhadap pembuat polisi bagi mengawal hutang isirumah dengan mencadangkan polisi yang lebih relevan dengan masyarakat setempat.

\section{METODOLOGI KAJIAN}

Kajian ini melibatkan dua buah model bagi menjawab objektif kajian. Model pertama untuk mengkaji faktor-faktor yang membezakan kelompok isi rumah yang berhutang dan tidak berhutang; manakala model kedua untuk mengkaji faktor-faktor yang mendasari pembentukan sikap isi rumah terhadap hutang. Regresi logistik binari digunakan kerana ia membenarkan 
pengkaji menilai sejauhmana set pembolehubah peramal iaitu pembolehubah tidak bersandar menjelaskan pembolehubah bersandar yang berbentuk kategori atau dikotomi (Pallant, 2010).

\section{Model 1: Faktor yang Membezakan Isi Rumah yang Berhutang dan Tidak Berhutang}

Model pertama melihat kepada fakor-faktor yang mempengaruhi kebarangkalian isi rumah berhutang atau tidak berhutang dengan fokus spesifik kepada sikap isi rumah. Pembolehubah tidak bersandar lain turut dimasukkan sebagai pembolehubah kawalan iaitu faktor ekonomi dan sosiodemografi. Faktor ekonomi yang dimasukkan ke dalam model pertama ialah pendapatan. Pendapatan merupakan salah satu faktor utama yang boleh menentukan kebarangkalian untuk berhutang kerana ia berkait rapat dengan penggunaan. Hipotesis yang mendasari faktor ini adalah isi rumah dengan pendapatan yang rendah cenderung untuk berhutang untuk menampung perbelanjaan.

Bagi faktor sosio-demografi, pembolehubah yang turut dimasukkan ke dalam model adalah umur, jenis pekerjaan, bilangan anak dan status perkahwinan. Umur dipertimbangkan berdasarkan Teori Model Kitaran Hayat. Menurut teori ini, umur seharusnya berkadar songsang dengan jumlah hutang disebabkan gologan muda perlu berhutang untuk membiayai pembelian barang atau perkhidmatan seperti rumah dan pendidikan, dan hutang ini akan dibayar sejajar dengan peningkatan usia. Jenis pekerjaan isi rumah juga turut memainkan peranan dalam menentukan kemungkinan seseorang itu berhutang atau tidak. Kebiasaannya, seseorang dengan pekerjaan yang relatif stabil seperti pekerja bergaji tetap mempunyai kebarangkalian untuk berhutang yang lebih tinggi kerana mereka mempunyai akses terhadap kemudahan pembiayaan hutang, selain mempunyai jangkaan terhadap pendapatan masa depan yang positif.

Pembolehubah bilangan anak pula dipilih untuk diuji dalam kajian ini kerana terdapat kajian yang menyatakan bilangan anak mempunyai hasil dapatan kajian yang pelbagai (Legge dan Heynes, 2009). Justeru, adalah menarik untuk memasukkan faktor bilangan anak sebagai pembolehubah tidak bersandar bagi menentukan sekiranya ianya dapat meramal keberhutangan isi rumah bandar di Malaysia.

Pembolehubah status perkahwinan dimasukkan berasaskan hipotesis mereka yang memiliki status perkahwinan ibu/bapa tunggal atau bercerai memiliki tahap kebarangkalian yang tinggi untuk berhutang berbanding dengan individu bujang atau berkahwin memandangkan mereka terpaksa 
menanggung kos hidup bersendirian. Penceraian juga akan memberikan impak terhadap situasi kewangan sesebuah keluarga di mana apabila berlaku penceraian maka pembahagian harta dan aset serta pengasingan tempat tinggal berlaku yang akhirnya akan memberikan kesan jangka pendek terhadap tahap ekonomi pasangan yang bercerai (Marshall, 2011). Ini mungkin mendorong mereka mengambil keputusan untuk melakukan pinjaman kredit atau dalam erti kata lain berhutang.

Berdasarkan itu, model pertama boleh ditulis seperti berikut manakala definisi dan butiran pembolehubah-pembolehubah diterangkan dalam Jadual 2:

$$
\begin{aligned}
& L=\operatorname{In}\left(\frac{\text { HUTANG }}{1-\text { HUTANG }}\right. \\
& =\beta_{0}+\beta_{1} \text { KOGNITIF }+\beta_{2} \text { TINGKAHLAKU }+\beta_{3} \text { EMOSI }+\beta_{4} \text { SPESIFIK }+ \\
& \beta_{5} \text { PENDAPATAN }(1)+\beta_{6} \text { PENDAPATAN }(2)+\beta_{7} \text { PENDAPATAN }(3)+ \\
& \beta_{8} \text { PENDAPATAN }(4)+\beta_{9} \text { UMUR }+\beta_{10} \text { STATUS PEKERJAAN }(1)+ \\
& \beta_{11} \text { STATUS PEKERJAAN }(2)+\beta_{12} \text { STATUS PEKERJAAN }(3)+\beta_{13} \text { BIL. } \\
& \text { ANAK }+\beta_{14} \text { STATUS PERKAHWINAN(1) + } \beta_{15} \text { STATUS } \\
& \text { PERKAHWINAN(2) }+\beta_{16} \text { STATUS PERKAHWINAN(3) }
\end{aligned}
$$

\section{Model 2: Faktor-faktor Pembentukan Sikap Isi Rumah Terhadap Hutang}

Model kedua pula melihat kepada fakor-faktor yang mempengaruhi kebarangkalian kecenderungan sikap terhadap hutang. Seperti dalam model pertama, pembolehubah-pembolehubah tidak bersandar dibahagikan kepada tiga bahagian iaitu pembolehubah psikologi, faktor-faktor ekonomi dan pembolehubah sosio-demografi.

Pembolehubah psikologi yang dipilih bagi mengkaji sikap isi rumah sama ada pro atau anti hutang ialah lokus kawalan dan perubahan sikap. Lokus kawalan dimasukkan berasaskan kepada kebanyakan dapatan kajian lepas menyimpulkan lokus kawalan seseorang menentukan kecenderungan indidvidu terhadap hutang, misalnya mereka yang mempunyai lokus kawalan luaran akan cenderung untuk bersikap pro hutang (Davies \& Lea, 1995; Cosma dan Pattarin, 2010; Livingstone dan Lunt, 1992) kerana merasakan nasib mereka dipengaruhi oleh faktor sekeliling atau nasib, jadi mereka tidak mempunyai motivasi untuk mengawal kedudukan kewangan mereka, dan ini diterjemahkan dari aspek menggunakan kemudahan kredit tanpa kawalan. 
Jadual 2: Definisi dan Keterangan Pembolehubah Model 1

\begin{tabular}{|c|c|}
\hline $\begin{array}{l}\text { Pembolehubah/ } \\
\text { Jenis data }\end{array}$ & Keterangan \\
\hline $\begin{array}{l}\text { L: Log bagi nisbah } \\
\text { odds kelompok } \\
\text { kumpulan yang } \\
\text { berhutang (dummy) }\end{array}$ & $\begin{array}{l}1=\text { Berhutang; } 0=\text { Tidak berhutang } \\
\text { Responden yang tidak mempunyai hutang (RM 0) } \\
\text { direkodkan dengan kod } 0 \text { (tiada hutang). Manakala } \\
\text { responden yang mempunyai jumlah hutang yang yang } \\
\text { positif (hutang }>0 \text { ) direkodkan dengan kod } 1\end{array}$ \\
\hline KOGNITIF: & $\begin{array}{l}\text { Jumlah skor skala Likert yang membentuk indeks kognitif } \\
\text { (Cosma \& Pattarin, 2010) }\end{array}$ \\
\hline AFEKTIF: & $\begin{array}{l}\text { Jumlah skor skala Likert yang membentuk indeks afektif } \\
\text { (Cosma \& Pattarin, 2010) }\end{array}$ \\
\hline TINGKAH LAKU: & $\begin{array}{l}\text { Jumlah skor skala Likert yang membentuk indeks tingkah } \\
\text { laku (Cosma \& Pattarin, 2010) }\end{array}$ \\
\hline SPESIFIK: & $\begin{array}{l}\text { Jumlah skor skala Likert yang membentuk indeks spesifik } \\
\text { terhadap hutang (Zhu \& Meeks, 1994) }\end{array}$ \\
\hline $\begin{array}{l}\text { Pendapatan bulanan } \\
\text { isirumah (dummy) }\end{array}$ & $\begin{array}{l}\text { PENDAPATAN = } 1 \text { untuk pendapatan bulanan isirumah } \\
\text { kurang sama dengan RM3000; } 0 \text { untuk sebaliknya } \\
\text { PENDAPATAN (1) = } 1 \text { untuk pendapatan bulanan } \\
\text { isirumah RM3001 hingga RM6000; } 0 \text { untuk sebaliknya } \\
\text { PENDAPATAN (2) = } 1 \text { untuk pendapatan bulanan } \\
\text { isirumah RM6001 hingga RM9000; } 0 \text { untuk sebaliknya } \\
\text { PENDAPATAN (3) = } 1 \text { untuk pendapatan bulanan } \\
\text { isirumah RM9001 hingga RM12000; } 0 \text { untuk sebaliknya } \\
\text { PENDAPATAN (4) = } 1 \text { untuk pendapatan bulanan } \\
\text { isirumah lebih dari RM12000; } 0 \text { untuk sebaliknya }\end{array}$ \\
\hline Umur (selanjar) & UMUR= Umur ketua isirumah (tahun) \\
\hline $\begin{array}{l}\text { Status pekerjaan } \\
\text { ketua isirumah: } \\
(\text { dummy })\end{array}$ & $\begin{array}{l}\text { STATUS PEKERJAAN }=1 \text { untuk Pekerja bergaji; } 0 \\
\text { untuk sebaliknya } \\
\text { STATUS PEKERJAAN }(1)=1 \text { untuk Bekerja sendiri; } 0 \\
\text { untuk sebaliknya STATUS PEKERJAAN }(2)=1 \text { untuk } \\
\text { Tidak bekerja; } 0 \text { untuk sebaliknya STATUS PEKERJAAN } \\
(3)=1 \text { untuk Lain-lain; } 0 \text { untuk sebaliknya }\end{array}$ \\
\hline $\begin{array}{l}\text { Bilangan anak } \\
\text { (selanjar) }\end{array}$ & BIL.ANAK = Bilangan anak (orang) \\
\hline $\begin{array}{l}\text { Status perkahwinan } \\
(\text { dummy) }\end{array}$ & $\begin{array}{l}\text { STATUS PERKAHWINAN }=1 \text { untuk Bujang; } 0 \text { untuk } \\
\text { sebaliknya } \\
\text { STATUS PERKAHWINAN (1) }=1 \text { untuk Berkahwin; } 0 \\
\text { untuk sebaliknya } \\
\text { STATUS PERKAHWINAN (2) = } 1 \text { untuk Balu/ Duda; } 0 \\
\text { untuk sebaliknya } \\
\text { STATUS PERKAHWINAN (3) }=1 \text { untuk Bercerai; } 0 \\
\text { untuk sebaliknya }\end{array}$ \\
\hline
\end{tabular}


Model ini turut menguji Teori Persepi Kendiri, (Plotnik dan Kouyoumdjian, 2008) yang menerangkan sikap seseorang individu boleh berubah melalui masa akibat pengalaman dan utiliti yang diperoleh daripada hutang. Dalam hal ini, isi rumah yang dapat menguruskan pembayaran balik hutang secara teratur mungkin cenderung untuk mempunyai sikap pro hutang. Pengujian hipotesis ini akan melibatkan pembolehubah langsung, iaitu pernyataan isi rumah terhadap keupayaan mereka mengendalikan pembayaran balik pinjaman bulanan secara teratur dan juga pembolehubah ekonomi iaitu jumlah kemudahan kredit (jumlah hutang) dan bilangan kad kredit yang dimiliki.

Kenyataan di atas adalah berasaskan kepada kajian lalu yang mendapati mereka yang bersikap pro hutang mempunyai gelagat penggunaan kad kredit yang pelbagai dan cenderung untuk memiliki bilangan kad kredit melebihi daripada satu kad (Wang et al., 2011; Hayhoe et al., 2005; Jirotmentree, 2010; Ramayah et al., 2002; Lee et al., 2011). Demikian juga dengan dapatan kajian oleh Wang et al., (2011), Davies dan Lea (1995), Livingstone dan Lunt (1992) dan Kim dan DeVaney (2001) iaitu mereka yang bersikap pro hutang akan cenderung untuk memiliki jumlah hutang yang tinggi kerana mereka mempunyai pandangan hutang bukan merupakan sesuatu yang negatif.

Pembolehubah ekonomi lain yang turut dimasukkan adalah pendapatan. Pendapatan dijangka mampu untuk mempengaruhi kecenderungan sikap isi rumah terhadap hutang kerana lazimnya, isi rumah dengan pendapatan yang tinggi lebih yakin dengan kemampuan mereka untuk membayar balik hutang, menyebabkan mereka lebih cenderung untuk berhutang. Berkait dengan pendapatan adalah tahap pendidikan. Tahap pendidikan juga boleh menentukan sikap terhadap hutang kerana semakin tinggi tahap pendidikan seseorang, berlaku peningkatan keyakinan untuk menguruskan kewangan mereka dengan lebih baik. Maka dalam kajian ini, tahap pendidikan dijangka mempunyai keupayaan untuk menganggarkan kebarangkalian sikap pro atau anti terhadap hutang.

Pembolehubah sosio-demografi lain yang dimasukkan ke dalam model ini ialah umur, agama, etnik dan tahap pendidikan tertinggi responden. Pembolehubah umur dipilih untuk diuji berasaskan penerangan hipotesis Livingstone dan Lunt (1992) yang menyatakan golongan muda mempunyai sikap yang lebih positif terhadap hutang kerana menerusi masa, perkembangan ekonomi yang berlaku seperti pengiklanan dan peningkatan akses kepada kemudahan kredit menyebabkan golongan yang relatif muda menerima tabiat berhutang sebagai sesuatu yang normal. 
Pembolehubah nilai pegangan, iaitu agama dan etnik dimasukkan untuk melihat pengaruh nilai ke atas sikap. Agama menentukan pegangan dan pandangan seseorang individu terhadap sesuatu isu. Islam, agama rasmi Malaysia melarang keras penganutnya untuk berhutang melainkan untuk menampung keperluan utama. Kajian ini menjangkakan isi rumah yang beragama Islam mempunyai keberangkalian untuk bersikap anti hutang. Demikian juga dijangkakan, faktor etnik yang mencerminkan budaya yang berbeza akan mempengaruhi pembentukan sikap. Perbezaan kesan etnik ke atas pengurusan kewangan, setakat ini mempunyai sokongan bukti empirik yang kuat dengan bangsa Cina dikenali sebagai bangsa yang mempraktikan konsep berjimat-cermat (Jie Jian) dan selalu menabung pendapatan mereka (Khee, 2008).

Fungsi persamaan model adalah seperti berikut manakala definisi dan butiran pembolehubah-pembolehubah diterangkan dalam Jadual 3:

\section{$L=$ In (PRO HUTANG/(1 - PRO HUTANG)}

$$
\begin{aligned}
= & \beta_{0}+\beta_{1} \text { UMUR }+\beta_{2} \text { AGAMA }(1)+\beta_{3} \operatorname{ETNIK}(1)+\beta_{4} \operatorname{ETNIK}(2)+ \\
& \beta_{5} \text { ETNIK }(3)+\beta_{6} \text { PENDIDIKAN }(1)+\beta_{7} \text { PENDIDIKAN }(2)+ \\
& \beta_{8} \text { PENDIDIKAN }(3)+\beta_{9} \text { PENDIDIKAN }(4)+\beta_{10} \text { PENDAPATAN }(1)+ \\
& \beta_{11} \text { PENDAPATAN }(2)++\quad \beta_{12} \text { PENDAPATAN }(3)+ \\
& \beta_{13} \text { PENDAPATAN }(4)+\beta_{14} \text { JUMLAH HUTANG }+\beta_{15} \text { BIL. KAD }+ \\
& \beta_{16} \text { LOKUS KAWALAN }+\beta_{17} \text { PENGURUSAN }
\end{aligned}
$$




\section{Jadual 3: Definisi dan Keterangan Pembolehubah Model 2}

\begin{tabular}{|c|c|}
\hline $\begin{array}{l}\text { Pembolehubah/Jenis } \\
\text { data }\end{array}$ & Keterangan \\
\hline $\begin{array}{l}\text { L: Log bagi nisbah } \\
\text { odds sikap kumpulan } \\
\text { yang berhutang } \\
\quad \text { (dummy) }\end{array}$ & $\begin{array}{l}1=\text { Pro terhadap hutang; } 0=\text { Anti terhadap berhutang } \\
\text { Berdasarkan Indeks skor komponen sikap }(27-95) \text {. } \\
(<48) \text { dan direkodkan dengan kod } 1 \text { sebagai pro terhadap } \\
\text { hutang ( }>48) \text { direkodkan dengan kod } 0 \text { iaitu mereka yang } \\
\text { memiliki sikap anti terhadap hutang }\end{array}$ \\
\hline $\begin{array}{l}\text { C14 = Pengurusan } \\
\text { komitmen kewangan } \\
\text { isirumah (selanjar) }\end{array}$ & $\begin{array}{l}\text { Jumlah skor skala Likert yang membentuk indeks soalan C14 : } \\
\text { "Saya membayar bil-bil mengikut masa yang ditetapkan" }\end{array}$ \\
\hline $\begin{array}{c}\text { Lokus kawalan } \\
\text { (selanjar) }\end{array}$ & $\begin{array}{l}\text { Jumlah skor skala Likert yang membentuk indeks lokus } \\
\text { kawalan (Cosma dan Pattarin, 2010) }\end{array}$ \\
\hline $\begin{array}{l}\text { Pendapatan bulanan } \\
\text { isirumah (dummy) }\end{array}$ & $\begin{array}{l}\text { PENDAPATAN = } 1 \text { untuk pendapatan bulanan isirumah } \\
\text { kurang sama dengan RM3000; } 0 \text { untuk sebaliknya } \\
\text { PENDAPATAN }(1)=1 \text { untuk pendapatan bulanan isirumah } \\
\text { RM3001 hingga RM6000; } 0 \text { untuk sebaliknya } \\
\text { PENDAPATAN }(2)=1 \text { untuk pendapatan bulanan isirumah } \\
\text { RM6001 hingga RM9000; } 0 \text { untuk sebaliknya } \\
\text { PENDAPATAN (3) = } 1 \text { untuk pendapatan bulanan isirumah } \\
\text { RM9001 hingga RM12000; } 0 \text { untuk sebaliknya } \\
\text { PENDAPATAN (4) = } 1 \text { untuk pendapatan bulanan isirumah } \\
\text { lebih dari RM12000; } 0 \text { untuk sebaliknya }\end{array}$ \\
\hline Bilangan kad kredit & $\begin{array}{l}\text { BIL. KAD = Bilangan kad kredit yang dimiliki termasuk kad } \\
\text { tambahan (unit) }\end{array}$ \\
\hline Umur (selanjar) & UMUR = Umur ketua isirumah (tahun) \\
\hline Agama (dummy) & AGAMA = 1 untuk Islam; 0 untuk sebaliknya \\
\hline Etnik (dummy) & $\begin{array}{l}\text { ETNIK = } 1 \text { untuk Melayu; } 0 \text { untuk sebaliknya } \\
\text { ETNIK }(1)=1 \text { untuk Cina; } 0 \text { untuk sebaliknya } \\
\text { ETNIK }(2)=1 \text { untuk India; } 0 \text { untuk sebaliknya } \\
\text { ETNIK }(3)=1 \text { untuk Lain-lain; } 0 \text { untuk sebaliknya }\end{array}$ \\
\hline $\begin{array}{l}\text { Tahap pendidikan } \\
\text { tertinggi ketua } \\
\text { isirumah (dummy) }\end{array}$ & 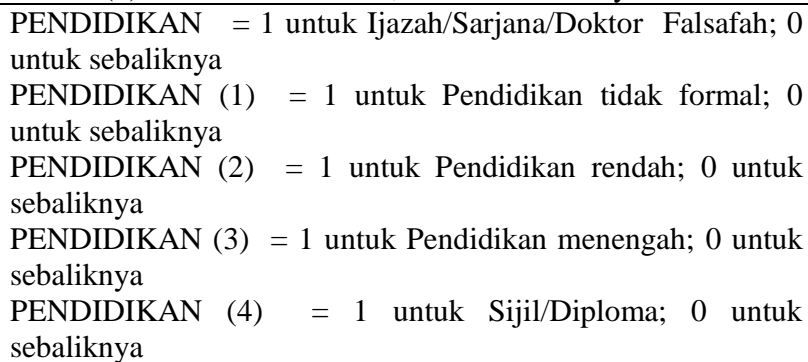 \\
\hline
\end{tabular}




\section{Pengumpulan data}

Kajian ini menggunakan data primer yang diperoleh menerusi survei yang dijalankan di antara bulan Januari dan April 2011. Responden terdiri daripada 1155 isi rumah yang bekerja di sekitar Lembah Klang, Malaysia. Semua responden berusia 18 tahun ke atas. Pemilihan sampel dilakukan menggunakan kaedah persampelan pelbagai peringkat strata (stratified multi-stage sampling method) yang membolehkan faktor sosio-ekonomi dan geografi diambil kira dalam menggambarkan populasi. Ujian rintis (pilot test) juga turut dilakukan pada Disember 2010 dengan menggunakan persampelan mudah (convenient sampling) dengan saiz sampel sebanyak 30 . Berdasarkan ujian rintis tersebut, pengubahsuaian butiran soal selidik dilakukan.

\section{DAPATAN KAJIAN DAN PERBINCANGAN}

\section{Analisis Pengesahan Faktor (Confirmatory Factor Analysis)}

Analisis dimulakan dengan analisis pengesahan faktor bagi memastikan indeks-indeks yang berkaitan dengan pembolehubah psikologi, boleh dipercayai dan dapat digunakan bagi mengukur pembolehubah sikap terhadap keberhutangan (kognitif, tingkah laku, emosi dan sikap spesifik) dan lokus kawalan (dalaman dan luaran). Indeks kesesuaian bagi setiap hipotesis model analisis pengesahan faktor yang ditunjukkan dalam Jadual 4 dan Rajah A mencadangkan bahawa model-model tersebut diterima, (Bentler dan Bonnet, 1988; Hu dan Bentler,1999; Yu, 2002). Dalam erti kata yang lain, pernyataan yang digunakan dapat mewakili pembolehubah pendam.

\section{Model 1}

Keputusan regresi Model 1 adalah seperti dalam Jadual 5. Berdasarkan nilai Ujian H-L, model ini memenuhi statistik model penyesuaian yang baik. Sebanyak $11.2 \%$ variasi dalam pembolehubah bersandar dapat diterangkan oleh model logistik pertama manakala nilai Nagelkerke $R$ Square bermaksud sebanyak $15 \%$ daripada perhubungan di antara pembolehubah yang diramal (isirumah berhutang atau tidak) dan pembolehubah peramal (pembolehubah psikologi, ekonomi dan sosio demografi) diterangkan oleh model.

Kajian sebelum ini kebanyakannya mendapati sikap positif terhadap hutang dari segi kognitif sudah cukup untuk mempengaruhi kebarangkalian 
isi rumah berhutang, (Hayhoe et al. 1999), Cosma dan Pattarin (2010) dan Haultain et al. (2010). Wang et al. (2011) dan Hayhoe et al. (2005) pula mendapati hanya isi rumah yang mempunyai sikap pro hutang secara afektif akan cenderung untuk mempunyai hutang. Sebaliknya, bagi kajian ini, didapati sikap pro hutang dari segi afektif dan kognitif, atau dari segi penerimaan konsep semata-mata tidak mencukupi untuk mempengaruhi kecenderungan isi rumah berhutang. Hanya sikap pro hutang dari aspek tingkah laku adalah cukup kuat untuk mempengaruhi isi rumah berhutang. Ini konsisten dengan penjelasan oleh Norvilitis et al. (2003) dan Zafar et al. (2010) yang menyatakan sebarang komponen sikap dari segi kognitif dan afektif yang terdapat dalam diri seseorang tidak semestinya akan diterjemahkan dalam bentuk tingkah laku, iaitu berhutang. Bagi faktorfaktor lain yang dimasukkan sebagai pembolehubah kawalan, kebanyakannya adalah konsisten dengan hipotesis awal, dan dapatan kajian terdahulu. Misalnya, kajian ini mendapati isi rumah yang berhutang adalah mereka yang berada dalam golongan kelas pertengahan. Dengan mengandaikan pembolehubah lain adalah konstan, kebarangkalian isi rumah yang mempunyai pendapatan bulanan sebanyak RM 3001 hingga RM 6000 untuk berhutang akan meningkat sebanyak 1.78 kali ganda berbanding dengan isi rumah yang berpendapatan kurang daripada RM 3000. 
Jadual 4 : OutputTerpilih Bagi Model Faktor Analisis

\begin{tabular}{|c|c|c|c|ccccccc|}
\hline \multirow{2}{*}{ Pembolehubah Pendam } & Pembolehubah Cerapan & $\chi^{2}$ & $d f$ & \multicolumn{6}{|c|}{ Garis tapak Perbandingan } \\
\cline { 5 - 6 } Sikap Terhadap Hutang & $\begin{array}{c}\text { Kognitif, Emosi, Tingkahlaku, } \\
\text { Sikap Spesifik }\end{array}$ & 14.13 & 2 & 0.075 & 0.981 & 0.943 & 0.984 & 0.951 & 0.984 \\
\hline Lokus Kawalan & D17, D18, D19,D20 & 6.886 & 2 & 0.047 & 0.993 & 0.964 & 0.995 & 0.974 & 0.995 \\
\hline
\end{tabular}

Petunjuk: $\chi^{2}=$ Chi Kuasa Dua, $d f=$ degree of freedom, RMSEA = Root mean square error of approximation, $\mathrm{NFI}=$ Normed fix index, RFI $=$ Relative fix index IFI =Incremental fix index,

$\mathrm{TLI}=$ Pekali Tucker-Lewis, $\mathrm{CFI}=$ Comparative fix index 
Rajah A: Output Laluan Diagram, Output Path Diagram (Model Akhir)

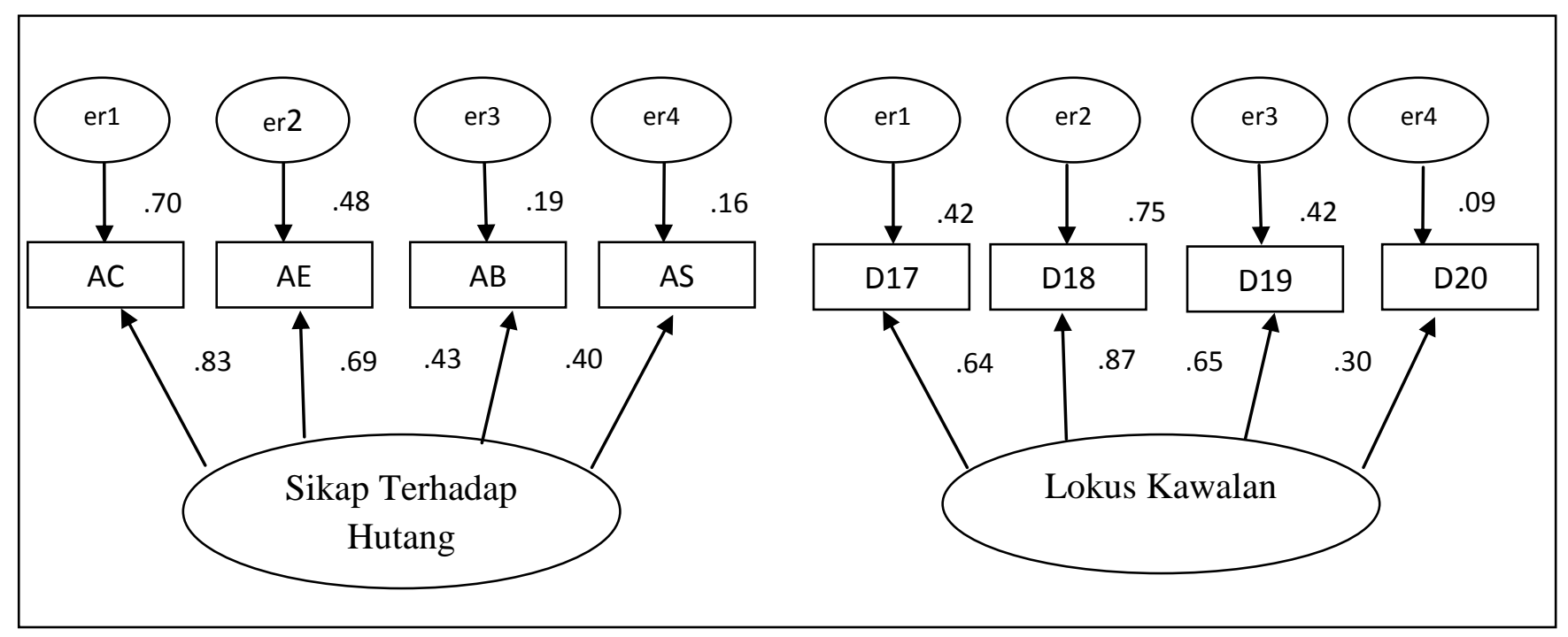


Jadual 5: Model Logistik 1

\begin{tabular}{|c|c|c|c|c|c|c|}
\hline Pembolehubah & $\beta$ & S.E & Wald & df & Sig. & $\begin{array}{c}\text { Odd } \\
\text { Ratio: } \\
\text { Exp (B) }\end{array}$ \\
\hline Pemalar $($ Constant $)$ & 1.570 & 1.007 & 2.430 & 1 & 0.119 & 4.805 \\
\hline $\begin{array}{l}\text { Pembolehubah } \\
\text { Psikologi }\end{array}$ & & & & & & \\
\hline Kognitif & 0.064 & 0.041 & 2.399 & 1 & 0.121 & 1.066 \\
\hline Tingkahlaku * & -0.202 & 0.057 & 12.737 & 1 & 0.000 & 0.817 \\
\hline Emosi & 0.007 & 0.064 & 0.011 & 1 & 0.916 & 1.007 \\
\hline Sikap spesifik* & -0.090 & 0.034 & 6.848 & 1 & 0.009 & 0.914 \\
\hline $\begin{array}{l}\text { Pembolehubah } \\
\text { Ekonomi } \\
\text { Pendapatan } \\
\text { Pendapatan(1)** } \\
\text { Pendapatan(2)*** } \\
\text { Pendapatan(3) } \\
\text { Pendapatan(4) }\end{array}$ & $\begin{array}{l}0.575 \\
0.784 \\
0.604 \\
0.688\end{array}$ & $\begin{array}{l}0.261 \\
0.424 \\
0.530 \\
0.569\end{array}$ & $\begin{array}{l}4.868 \\
3.423 \\
1.296 \\
1.461\end{array}$ & $\begin{array}{l}1 \\
1 \\
1 \\
1\end{array}$ & $\begin{array}{l}0.027 \\
0.064 \\
0.255 \\
0.227\end{array}$ & $\begin{array}{l}1.777 \\
2.191 \\
1.829 \\
1.989\end{array}$ \\
\hline $\begin{array}{l}\text { Pembolehubah Sosio- } \\
\text { Demografi } \\
\text { Umur (tahun) } \\
\text { Bilangan anak (org) }\end{array}$ & $\begin{array}{r}0.006 \\
-0.002\end{array}$ & $\begin{array}{l}0.013 \\
0.077\end{array}$ & $\begin{array}{l}0.198 \\
0.001\end{array}$ & $\begin{array}{l}1 \\
1\end{array}$ & $\begin{array}{l}0.656 \\
0.975\end{array}$ & $\begin{array}{l}1.006 \\
0.998\end{array}$ \\
\hline $\begin{array}{l}\text { Status perkahwinan } \\
\text { Status perkahwinan(1) } \\
\text { Status perkahwinan (2) } \\
\text { Status perkahwinan }(3)^{* *}\end{array}$ & $\begin{array}{r}0.386 \\
-0.905 \\
1.678\end{array}$ & $\begin{array}{l}0.364 \\
0.925 \\
0.905\end{array}$ & $\begin{array}{l}1.126 \\
0.958 \\
3.436\end{array}$ & $\begin{array}{l}1 \\
1 \\
1\end{array}$ & $\begin{array}{l}0.289 \\
0.328 \\
0.064\end{array}$ & $\begin{array}{l}1.471 \\
0.404 \\
5.357\end{array}$ \\
\hline $\begin{array}{l}\text { Status pekerjaan } \\
\text { Status pekerjaan }(1)^{* * *} \\
\text { Status pekerjaan }(2) \\
\text { Status pekerjaan(3) }\end{array}$ & $\begin{array}{r}-0.421 \\
-0.700 \\
0.585\end{array}$ & $\begin{array}{l}0.258 \\
0.461 \\
0.693\end{array}$ & $\begin{array}{l}2.670 \\
2.310 \\
0.713\end{array}$ & $\begin{array}{l}1 \\
1 \\
1\end{array}$ & $\begin{array}{l}0.102 \\
0.129 \\
0.398\end{array}$ & $\begin{array}{l}0.657 \\
0.496 \\
1.795\end{array}$ \\
\hline
\end{tabular}

$\beta$ : Pekali Anggaran

* Signifikan pada 1\%, ** Signifikan pada 5\%,*** Signifikan pada 10\% Ujian Hosmer-Lemeshow (H-L): 7.271 (nilai-p = 0.508), Ujian Cox dan Snell: 0.112, Ujian Nagelkerke: 0.295 
Di samping itu, isi rumah yang berpendapatan di antara RM6001 hingga RM9000 juga turut didapati mempunyai perhubungan yang signifikan dengan kedudukan berhutang dengan kebarangkalian untuk berhutang meningkat sebanyak 2.91 kali ganda berbanding isi rumah yang mempunyai pendapatan kurang daripada RM3000. Ini selari dengan dapatan kajian lepas oleh Riiser dan Vatne (2006) yang mendapati golongan kelas berpendapatan pertengahan sememangnya cenderung untuk memiliki hutang dan kajian Kamleitner dan Kirchler (2007) yang menyatakan golongan kelas pertengahan sebagai pengguna utama kredit komersial.

Dapatan yang bertentangan dengan kebanyakan kajian lepas adalah faktor usia. Dalam kes yang dikaji di kawasan Lembah Klang ini, umur tidak mempengaruhi kecenderungan isi rumah berhutang. Ini bercanggah dengan kebanyakan dapatan kajian lepas yang mendapati faktor usia mempunyai kesan terhadap hutang (Legge dan Haynes, 2009; Livingstone dan Lunt, 1992; Awh dan Waters, 1974; Cox dan Jappelli, 1993). Ini mungkin disebabkan kajian ini tidak mengasingkan jenis pinjaman, sebaliknya hanya mengasingkan kepada isi rumah yang berhutang dan tidak berhutang, sedangkan menurut Marshall (2011) dan Lee et al. (2007), keputusan untuk berhutang adalah berbeza dari segi jenis hutang dan tahap keberhutangan. Golongan yang berusia lebih lanjut mungkin tidak mempunyai hutang bercagar seperti pinjaman perumahan tetapi masih menggunakan kredit penggunaan (Wickramasinghe dan Gurugamage, 2012).

Dapatan kajian mendapati hanya dua pembolehubah sikap yang mempunyai kesan terhadap kecenderungan isi rumah untuk berhutang iaitu komponen sikap tingkah laku dan indeks spesifik. Indeks spesifik merujuk kepada setakat mana isi rumah merasakan tidak salah untuk menggunakan kredit bagi membeli barangan tertentu seperti barang kemas, melancong, perbelanjaan hidup, kereta dan perbelanjaan pendidikan yang lebih dominan.

Pekali kedua-dua pembolehubah yang negatif bermaksud isi rumah yang bersikap pro hutang mempunyai kebarangkalian yang tinggi untuk mempunyai hutang. Isi rumah yang memiliki sikap yang positif terhadap hutang dari segi sikap tingkah laku menggunakan pengukuran indeks spesifik akan mempunyai kebarangkalian untuk mempunyai hutang masingmasing sebanyak 0.82 dan 0.91 kali ganda.

Hubungan yang signifikan antara sikap, menggunakan pengukuran spesifik, dan kebarangkalian isi rumah untuk berhutang adalah consistent dengan Chien dan DeVaney (2001), Zhu dan Meek (1994) dan Kim dan DeVaney (2001). Sementara itu, dapatan yang menunjukkan hanya komponen sikap tingkah laku yang signifikan dalam menjelaskan 
kemungkinan isi rumah untuk berhutang adalah unik untuk kajian di Malaysia.

\section{Model 2}

Model ini menepati kriteria statistik model yang baik, berasaskan kepada nilai ujian Hosmer-Lemeshow. Ujian Nagelkerke pula model ini menjelaskan $40.2 \%$ variasi dalam pembolehubah bersandar iaitu sama ada isi rumah bersikap pro atau anti hutang.

Keputusan regressi menunjukkan kebanyakan faktor yang menerangkan sikap isi rumah sama ada pro atau anti terhadap hutang adalah konsisten dengan hipotesis awal. Sebagaimana ditunjukkan di dalam Jadual 6 , faktor yang mempengaruhi sikap isi rumah terhadap hutang adalah lokus kawalan, pendapatan bulanan isi rumah, jumlah hutang, bilangan kad kredit, umur, agama, etnik dan memiliki tahap pendidikan tidak formal.

Bagaimanapun, arah hubungan lokus kawalan dengan sikap terhadap hutang adalah berbeza dengan dapatan kajian terdahulu. Dalam kajian ini, mereka yang memiliki lokus kawalan luaran yang didapati akan cenderung untuk bersikap anti hutang sedangkan hampir semua kajian lepas mendapati individu yang memiliki lokus kawalan luaran akan cenderung untuk bersikap pro hutang (Davies dan Lea, 1995; Cosma dan Pattarin, 2010; Livingstone dan Lunt, 1992).

Penerangan yang mungkin adalah isi rumah yang memiliki lokus kawalan luaran kurang yakin tentang keupayaan diri mereka untuk menentukan kesan akhir, ini mendorong mereka untuk bersikap anti hutang disebabkan tidak yakin terhadap kemampuan mereka untuk mengurus pembayaran balik pinjaman yang bakal dilakukan. Apa yang menarik adalah keputusan ini selari dengan dapatan kajian oleh Wang et al. (2011) yang menyatakan individu yang memiliki lokus kawalan luaran akan mengelak dari memiliki terlalu banyak hutang. Kajian oleh Wang et al., (2011) juga dilakukan di negara timur, iatu China berbanding kajian yang menemui keputusan bertentangan, dilakukan di negara barat, (Davies dan Lea, 1995; Cosma dan Pattarin, 2010; Livingstone dan Lunt, 1992). Besar kemungkinan, perbezaan sikap terhadap hutang berikutan perspektif terhadap keupayaan diri mengawal keputusan akhir mempunyai kaitan dengan nilai sesebuah masyarakat. 
Jadual 6: Model logistik 2

\begin{tabular}{|c|c|c|c|c|c|c|}
\hline Pembolehubah & $\boldsymbol{\beta}$ & S.E & Wald & df & Sig. & $\begin{array}{c}\text { Odd } \\
\text { Ratio: } \\
\text { Exp (B) }\end{array}$ \\
\hline Pemalar (Constant) & 3.130 & 1.168 & 7.177 & 1 & 0.007 & 22.876 \\
\hline Pembolehubah Psikologi & & & & & & \\
\hline Lokus kawalan* & -0.292 & 0.076 & 14.828 & 1 & 0.000 & 0.747 \\
\hline Pengurusan kewangan & 0.254 & 0.167 & 2.313 & 1 & 0.128 & 1.290 \\
\hline Pembolehubah Ekonomi & & & & & & \\
\hline Pendapatan & & & 7.655 & 4 & 0.105 & \\
\hline Pendapatan(1) & 0.116 & 0.427 & 0.074 & 1 & 0.786 & 1.123 \\
\hline Pendapatan $(2)^{* *}$ & 2.765 & 1.234 & 5.022 & 1 & 0.025 & 15.884 \\
\hline Pendapatan(3) & -0.058 & 0.810 & 0.005 & 1 & 0.942 & 0.943 \\
\hline Pendapatan $(4) * * *$ & 2.028 & 1.231 & 2.715 & 1 & 0.099 & 7.597 \\
\hline Jumlah hutang $(\mathrm{RM}) * * *$ & 0.000 & 0.000 & 2.652 & 1 & 0.103 & 1.000 \\
\hline Bilangan kad kredit*** & 0.344 & 0.181 & 3.614 & 1 & 0.057 & 1.410 \\
\hline Pembolehubah Sosio-Demografi & & & & & & \\
\hline Umur (tahun)** & -0.053 & 0.022 & 5.767 & 1 & 0.016 & 0.949 \\
\hline Agama & & & & & & \\
\hline $\operatorname{Agama}(1) * *$ & 2.220 & 1.045 & 4.514 & 1 & 0.034 & 9.205 \\
\hline Etnik $* * *$ & & & 7.305 & 3 & 0.060 & \\
\hline $\operatorname{Etnik}(1) * *$ & -2.220 & 1.052 & 4.456 & 1 & 0.035 & 0.109 \\
\hline $\operatorname{Etnik}(2)$ & -0.978 & 1.216 & 0.646 & 1 & 0.421 & 0.376 \\
\hline $\operatorname{Etnik}(3) * *$ & -2.712 & 1.250 & 4.707 & 1 & 0.030 & 0.066 \\
\hline Pendidikan $* * *$ & & & 8.124 & 4 & 0.087 & \\
\hline Pendidikan(1) & -1.286 & 1.200 & 1.149 & 1 & 0.284 & 0.276 \\
\hline Pendidikan(2) & -0.494 & 0.915 & 0.292 & 1 & 0.589 & 0.610 \\
\hline Pendidikan(3) & -0.210 & 0.523 & 0.160 & 1 & 0.689 & 0.811 \\
\hline Pendidikan $(4)^{* *}$ & 0.949 & 0.455 & 4.357 & 1 & 0.037 & 2.584 \\
\hline
\end{tabular}

$\beta$ : Pekali Anggaran

* Signifikan pada 1\%, ** Signifikan pada 5\%,*** Signifikan pada $10 \%$

Ujian Hosmer-Lemeshow (H-L): 11.467 (nilai-p = 0.177), Ujian Cox dan Snell: 0.295, Ujian Nagelkerke: 0.402 . 
Ini berkait dengan dapatan kajian seterusnya mengenai keupayaan nilai dan pegangan yang didapati sangat mempengaruhi sikap isi rumah terhadap hutang. Dari segi agama, isi rumah yang bukan beragama Islam akan cenderung untuk bersikap pro hutang sebanyak 9.21 kali ganda berbanding dengan isi rumah yang beragama Islam. Dari segi jenis etnik pula, dapatan kajian menunjukkan isi rumah yang berbangsa Cina dan Lainlain kurang cenderung untuk bersikap pro hutang sebanyak 0.11 kali ganda berbanding isi rumah yang berbangsa Melayu dan trend yang sama turut dicatatkan bagi isi rumah yang berbangsa Lain-lain yang dijangka memiliki kebarangkalian yang rendah untuk bersikap pro hutang sebanyak 0.07 kali ganda berbanding isi rumah berbangsa Melayu.

Dapatan kajian lepas yang menyokong premis bahawa etnik Cina kurang cenderung untuk bersikap pro hutang adalah Tan et al. (2011) yang mendapati mereka yang berbangsa Cina cenderung untuk memiliki satu, lima atau lebih kad kredit berbanding dengan bangsa lain namun dari segi tahap penggunaan kad kredit, mereka yang bangsa Cina didapati mempunyai jumlah hutang yang lebih rendah berbanding dengan bangsa lain kerana hanya menggunakan kad kredit sebagai medium transaksi.

Kajian ini juga turut cuba untuk meramalkan sekiranya Teori Persepsi Kendiri yang dicadangkan oleh Plotnik dan Kouyoumdjian (2008) dapat dipenuhi iaitu sikap seseorang individu boleh berubah melalui masa akibat pengalaman dan utiliti yang diperoleh daripada berhutang. Dari segi pembolehubah langsung yang digunakan untuk menguji hipotesis ini, tiada bukti yang menyatakan isirumah yang mampu untuk menjelaskan bayaran balik hutang setiap bulan secara teratur bersikap pro hutang.

Walau bagaimanapun, bukti empirikal yang diperoleh menunjukkan jumlah hutang dan pemilikan kad kredit membezakan golongan pro dan anti hutang. Ini mengisyaratkan isi rumah yang memiliki hutang berkemungkinan menjadi lebih pro kredit sekaligus menyokong Teori Persepsi Kendiri. Merujuk kepada Jadual 6, dari segi kesan saiz, sekiranya jumlah hutang isi rumah meningkat sebanyak RM1, maka kebarangkalian untuk isi rumah bersikap pro hutang meningkat sebanyak sekali ganda (Exp (B) = 1.000) manakala dari segi pemilikan kad kredit, dapatan kajian mendapati tambahan satu kad kredit oleh isi rumah, maka kecenderungan isi rumah untuk bersikap pro hutang meningkat sebanyak 1.41 kali ganda (Exp $(B)=1.410)$. Sikap pro atau anti hutang juga bergantung kepada pendapatan, iaitu isi rumah yang berpendapatan bulanan RM6001 hingga RM9000 dan RM12,000 mempunyai keberangkalian yang tinggi untuk bersikap pro hutang. 
Tahap pendidikan turut didapati mempunyai perhubungan terhadap sikap isi rumah terhadap hutang. Isi rumah dengan tahap pendidikan tertinggi peringkat sijil atau diploma, Ijazah, Sarjana atau Doktof Falsafah mempunyai kebarangkalian yang positif untuk bersikap pro hutang Dapatan ini selari dengan dapatan kajian lepas yang mendapati semakin tinggi tahap pendidikan seseorang semakin tinggi kecenderungan mereka untuk bersikap pro hutang (Wickramasinghe \& Gurugamage, 2012; Lee et al., 2007; Lee et al., 2011; Zuroni \& Lin, 2012).

Jelasnya, keputusan kajian ini menunjukkan faktor sikap terhadap hutang menerangkan keputusan isi rumah untuk berhutang. Bagaimanapun, mereka yang berhutang adalah mereka yang bersikap pro hutang dari aspek tingkah laku. Isi rumah yang mempunyai sikap positif terhadap hutang, sekadar secara persepsi (kognitif) atau emosi, belum cukup untuk memotivasikan mereka untuk berhutang. Manakala persoalan tentang pembentukan sikap isi rumah terhadap hutang pula mencadangkan ia melibatkan dua dimensi utama, iaitu nilai pegangan yang melibatkan faktor seperti agama dan bangsa; serta dimensi persepsi kendiri.

Ini mencadangkan sikap isi rumah di Lembah Klang terhadap hutang, sebahagiannya merupakan yang terbentuk secara semulajadi disebabkan nilai pegangan yang dipupuk sedari kecil. Manakala sebahagian yang lain terbentuk daripada proses kebiasaan berhutang, yang mungkin bermula daripada keperluan terhadap hutang misalnya untuk membiayai keperluan seperti membeli rumah; berikutan itu, gaya hidup beli dahulu bayar kemudian ini menjadi kebiasaan yang menyenangkan, dan menukar sikap isi rumah kepada pro hutang.

Keseluruhannya, keputusan kajian menunjukkan sikap isi rumah terhadap hutang merupakan antara faktor yang menyebabkan isi rumah berhutang. Apa yang memerlukan tumpuan adalah faktor yang membentuk sikap terhadap hutang sendiri. Bukti empirik menunjukkan sikap isi rumah dibentuk oleh nilai pegangan yang disemai sedari kecil dan hasil dari pengalaman penggunaan hutang sendiri. Pembentukan sikap dari aspek pengalaman kendiri memperlihatkan agak sukar untuk mengubah sikap masyarakat terhadap hutang, daripada pro kepada anti hutang. Sebahagiannya telah tersemai dalam diri berasaskan pegangan, sebahagiannya pula dipengaruhi oleh kebiasaan berhutang sendiri, dan dalam zaman ini, berhutang untuk membiayai barangan seperti rumah dan kereta, di usia muda adalah perkara biasa.

Maka, individu yang anti hutang juga berkemungkinan akan menjadi pro hutang setelah mula berhutang untuk membiayai pembelian barangan seperti rumah dan kereta. Bagaimanapun, sebahagian aspek lagi, 
iaitu nilai pegangan mengisyaratkan wujud peluang untuk membentuk sikap yang lebih anti hutang menerusi pendidikan sedari peringkat awal persekolahan. Dengan ini, isi rumah akan bersikap lebih anti hutang seterusnya mengurangkan keputusan untuk berhutang, khususnya untuk membiayai barangan yang tidak perlu.

\section{KESIMPULAN}

Kajian ini dijalankan bagi melihat adakah sikap isi rumah terhadap hutang menerangkan sebahagian daripada permasalahan keberhutangan isi rumah kebelakangan ini. Selain itu, kajian turut melihat kepada apakah pula faktor yang mendasari pembentukan kecenderungan sikap isi rumah terhadap hutang. kajian ini hanya memfokuskan kepada masyarakat bandar di Lembah Klang, disebabkan kos yang terhad. Sebagaimana yang dijangka, keputusan kajian tidak berbeza dengan kebanyakan kajian terdahulu yang kebanyakannya dijalankan di negara barat, iatu sikap mempengaruhi keputusan isi rumah untuk berhutang. Bagaimanapun, dapatan yang unik dalam kes ini adalah hanya sikap pro hutang dari segi tingkah laku yang mempengaruhi isi rumah untuk berhutang, sedangkan dalam masyarakat barat lain, sikap pro hutang dari aspek persepsi dan emosi sahaja sudah cukup untuk memotivasikan isi rumah untuk berhutang. Manakala jika dilihat dari aspek faktor yang mempengaruhi pembentukan sikap terhadap hutang, ia melibatkan dua dimensi utama iaitu persepsi kendiri dan nilai pegangan. Dimensi yang pertama tidak banyak memberikan ruang untuk intervensi polisi, diberikan perkembangan dunia hari ini di mana kemudahan pembiayaan kredit diperlukan sekurang-kurangnya untuk membiayai pembelian barangan seperti rumah dan kereta. Bagaimanapun, dimensi kedua mencadangkan ruang untuk campur tangan polisi, iaitu menerusi pendidikan. Pendidikan dari bangku sekolah tentang keburukan hutang khususnya untuk membiayai pembelian barangan bukan keperluan dan kepentingan menabung, boleh membantu untuk mengelakkan kecenderungan masyarakat terhadap penggunaan hutang yang berlebihan dan seterusnya dapat menjamin kesejahteraan sosial sesebuah komuniti.

\section{RUJUKAN}

Abdul-Muhmin, A.G., \& Umar, Y.A. (2004). Attitudes towards credit and credit cards among consumers in Saudi Arabia: A preliminary investigation. Diperoleh pada 8 Jun, 2012 dari http://faculty.kfupm.edu.sa/coe/sadiq/proceedings 
/SCAC2004/45.ASC079.EN.Muhmin\&Umar.Attitudes\%20Toward\% 20Credit\%20and\%20Cre\%20_1_.pdf.

Ajzen, Icek. 1996. The Social Psychology of Decision Making. In Social Psychology:Handbook of Basic Principles, edited by E. Troy Higgins and Arie W. Kruglanski, New York: Guilford Press.

Awh, R.Y., \& Waters, D.(1974). Discriminant Analysis of Economic, demographic, and attitudinal characteristics of bank charge-card holders: A case study. The Journal of Finance, 29(3): 973-980.

Bentler, P. M., \& Bonett, D. G. (1988). Significance tests and goodness of fit in the analysis of covariance structures. Psychological Bulletin, 88, 588-606.

Cosma, S., \& Pattarin, F. (2010). Attitudes, personality factors and household debt decisions: A study of consumer credit. Diperoleh pada 27 Januari, 2011, dari http://ssrn.com/abstract=1685765 or http://dx.doi.org/10.2139/ssrn.1685765.

Cox, D., \& Jappelli, J. (1993). The effect of borrowing constraints on consumer liabilities. Journal of Money, Credit, and Banking, 25 (2): 197-213.

Davies, E., \& Lea, S.E.G. (1995). Student attitudes to student debt. Journal of Economic Psychology 16 (4): 663-679.

Haultain, S., Kemp, S., \& Chernyshenko, O.S. (2010). The structure of attitude to student debt. Journal of Economic Psychology 31(3): 322330.

Hayhoe, C.R., Leach, L., Allen, M.W., \& Edwards, R. (2005). Credit card held by college students. Association for Financial Counseling and Planning Education, 16 (1): 1-10.

Hayhoe, C.R., Leach, L., \& Turner, P.R. (1999). Discriminating the number of credit cards held by college students using credit and money attitudes. Journal of Economic Psychology, 20 (6): 643-656.

Hu, L.T., \& Bentler, P. M. (1999). Cut-off criteria for fit indices in covariance structure analysis: Conventional criteria versus new alternatives. Structural Equation Modeling. 6: 1-55.

Jirotmontree, A. (2010). Credit card use among Bangkok cardholders: An exploration into credit card attitudes, debt and strategy improvement. ABAC Journal, 30 (3): 15-29.

Kamleitner, B., \& Kirchler, E. (2007). Consumer credit use: a process model and literature review. Revue europeenne de psychologic appliquée, 57 (4): 267-283.

Kee, C. E. (2010). Household debt: Red flags ahead? Diperoleh pada 27 Januari, 2011 dari 
http://findarticles.com/p/articles/mi_qn6207/is_20101101/ai_n562760 38/.

Khee, P.C. (2008). Insight of Chinese economics culture in Malaysia. International Journal of Business and Management, 3 (9): 65-73.

Kim, H., \& DeVaney, S.A. (2001). The determinants of outstanding balances among credit card revolvers. Association for Financial Counseling and Planning, 12(1): 67-77.

Lee, Y.G., Lown, J.M., \& Sharpe, D.L. (2007). Predictors of holding consumer and mortgage debt among older Americans. Journal of Family and Economics Issues, 28 (2): 305-320.

Legge, J., \& Heynes, A. (2009). Beyond reasonable debt: a background report on the indebtedness of New Zealand families. Social Policy Journal of New Zealand, 35: 28-42.

Livingstone, S.M., \& Lunt P.K. (1991). Psychological, social and economic determinants of saving: comparing recurrent and total savings. Journal of Economic Psychology 12 (4): 621-641.

Maio, G. R., \& Haddock, G. (2010). The psychology of attitudes and attitude change. Diperoleh pada 27 Januari, 2011 dari http://books.google.com.my/books?hl=en\&lr=\&id=uAp6KlCk0HIC\& oi=fnd\&pg=PR5\&ots=q8gp_ID0RX\&sig=oe1peJKRkoxM_n2uCNd3 MiFVPqw\# $=$ onepage $\& q \& \mathrm{f}=$ false

Marshall, K. (2011). Retiring with debt. Components of Statistics Canada Catalogue:Perspectives on Labour and Income. . Diperoleh pada 27 Januari, 2011 dari www.statcan.gc.ca/pub/75-001x/2011002/pdf/11428 eng.pdf

Olsen, M. A., \& Kendrick, R .V. (2008). Origins of attitudes. In W. D. Crano \& W. D. Prislin (Eds.), Attitudes and Attitude Change, (pp. 111-130). Diperoleh pada 27 Januari, 2011 darihttp://libepl.um.ac.ir/parameters/libepl/filemanager/ebook/e2/List $\% 201 / 21 . \% 20$ Attitudes\%20and\%20Attitude\%20Change\%20\%20Fro ntiers\%20of\%20Social\%20Psychology\%20(978-1841694818). pdf\#page $=126$

Pallant, J. (2010). SPSS survival manual: A step by step guide to data analysis using SPSS. McGraw-Hill Education.

Peng, C.Y.J., Lee, K.L., \& Ingersoll, G.M. (2002). An introduction to logistic regression analysis and reporting. The Journal of Educational Research 96 (1): 3-14.

Plotnik, R., \& Kouyoumdjian, H. (2008). Introduction to psychology $\left(9^{\text {th }}\right.$ Edition). United States of America: Wadsworth Cengage Learning. 
Ramayah, T., Nasser, N., Aizzat, M..N., \& Choo, L.H. (2002). Cardholders' attitude and bank credit card usage in Malaysia: An exploratory study. Asian Academy of Management Journal 7 (1): 75-102.

Riiser, M.D., \& Vatne, B.H. (2006). Developments in household debt: An analysis of microdata for the period 1986-2003. Norges Bank 77. Diperolehi dari http://www.freepatentsonline.com/article/EconomicBulletin/ 149514696.html.

S.M. Mohamed, I. (2011). Household Debt in Malaysia-Is It Sustainable?. Diperoleh pada 27 Januari, 2011 dari http://www.themalaysianinsider.com/breakingviews/article/household -debt-in-malaysia-is-it-sustainable-s.m.mohamed-idris/

Tan, A.K.G., Yen, S.T., Loke, Y.J. (2011). Credit card holders, convenience users and revolvers: A tobit model with binary selection and ordinal treatment. Journal of Applied Economics 14 (2): 225-255.

Universities UK. (2003). Attitudes to debt. Diperoleh pada 27 Januari, 2011 dari www.UniversitiesUK.ac.uk/studentdebt. Wang, L., Lu, W., \& Malhotra, N.K. (2011). Demographics, attitude, personality and credit card features correlate with credit card debt: A view from China. Journal of Economic Psychology 32 (1): 179-193.

Wickramasinghe, V., \& Gurugamage, A. (2012). Effects of social demographic attributes, knowledge about credit cards and perceived lifestyle outcomes on credit card usage. International Journal of Consumer Studies 36: 80-89.

Yilmazer, T., \& DeVaney, S.A. (2005). Household debt over the life cycle. Financial Services Review 14: 286-304.

Yu, C. Y. (2002). Evaluation of model fit indices for latent variable models with categorical and continuous outcomes. Unpublished dissertation. $\begin{array}{llll}\text { Diperoleh } & \text { pada } & 27 & \text { Januari, }\end{array}$ http://www.statmodel.com/download/Yudissertation.pdf.

Zafar, U.A., Ishak, I., Sohail, M.S., Ibrahim, T., \& Hasbalaila, A. (2010). Malaysian consumers' credit card usage behaviour. Asia Pacific Journal of Marketing and Logistics 22 (4): 528 - 544.

Zhu, L.Y., \& Meeks, C.B. (1994). Effects of low income families' ability and willingness to use consumer credit on subsequent outstanding credit balances. Diperolehi dari http://findarticles.com/p/articles/mi_hb3250/is_n2_v28/ai_n28649564 l.

Zuroni, M.J., \& Lin, L.Y. (2012). Personal financial knowledge and attitude towards credit card practices among working adults in Malaysia. International Journal of Business and Social Science 3: 176-185. 